\title{
THE BMA'S GUIDANCE ON CONSCIENTIOUS OBJECTION MAY BE CONTRARY TO HUMAN RIGHTS
}

LAW

\section{Introduction}

The Supreme Court ('SC') has recently provided guidance on the meaning of the conscience clause under the Abortion Act in the case of Doogan. ${ }^{1}$ It held that the conscience clause, while allowing two senior nurses to object to carrying out abortions, did not allow them from refusing to provide supervisory and administrative assistance to the other medical professionals that were providing abortions. The SC however explicitly accepted that that was not the end of the matter. It stated that the two nurses could have a human right to conscientiously object to supervising and providing administrative assistance in abortion cases. However, the Court, in paragraph 25 of its judgment, decided not to give a pronouncement on that issue and left the point to be decided in future litigation.

The SC's refusal to pronounce on the human rights perspective on conscientious objection to abortion or other medical services provides the occasion to identify whether that guidance is available elsewhere and to examine the stance on conscientious objection of the British Medical Association ('BMA') in light of that alternative guidance. The focus here on the BMA's guidance is justified by the fact that, as will be shown, the guidance is more restrictive than that of the General Medical Council, the medical profession's regulator. Furthermore, given that the BMA, as the profession's trade union, is likely to be one of the first sources of legal advice for a doctor wishing to exercise the right to conscientiously object, it is important that the BMA's guidance be an accurate reflection of doctors' legal rights.

In its policy paper 'Expression of Doctors' Beliefs' ${ }^{2}$ the BMA has expressed the view that there is a right to conscientious objection only in three specific areas where it has been able to identify a statutory or otherwise legal ground for such a right. The BMA does not consider that medical professionals have a 'right' to conscientious objection in other circumstances, although it is willing to accept that 'requests to exercise a conscientious objection in relation to other procedures should ordinarily be considered ${ }^{3}{ }^{3}$ In contrast, the GMC's guidance does not restrict the right to object to any particular medical service but instead cautions that such objection should not result in discrimination or harassment of patients. ${ }^{4}$

This paper shows that, despite the SC's refusal to provide guidance on the human right to conscientious objection in a medical context, guidance has already been provided by the European Court of Human Rights ('ECtHR') in the case of Eweida. ${ }^{5}$ The UK Human Rights Act ('HRA') makes enforceable against NHS institutions the European Convention on Human Rights ('ECHR') as interpreted by the ECtHR. Article 9 of the ECHR ('art. 9') protects the right to freedom of conscience and religion. That right, as interpreted by the ECtHR, effectively provides that medical professionals have the right to conscientiously object to providing certain healthcare services well beyond the scope endorsed by the BMA.

Admittedly, as will be shown, the fact that there is a full fledge legal right to conscientious objection does not mean that once that right is invoked by a doctor he can legitimately refuse to perform a 
service. However, it entails that, on a very practical level, the NHS employer will have to consider the request and, with appropriate legal advice (and its related costs), determine whether denying the request is a legitimate interference with a Convention right. It also entails that, contrary to the present BMA's position, NHS employers actually have a legal duty to consider requests to exercise conscientious objection in areas other than the three currently recognised by the BMA and, importantly, they have a legal duty to grant those requests when appropriate.

Given the unsettled nature of the law on the topic, NHS employers will have to proceed very cautiously as it will not always be clear whether denying a request will be considered lawful by a court. This entails that NHS bodies may be at risk of expensive legal challenges by medical professionals whose requests have been denied. In sum, if the main arguments of this paper are correct, the BMA's current policy restricting the right to conscientious objection only to three specific areas ought to be changed.

\section{The British Medical Association's Guidance on Conscientious Objection}

The BMA has distanced itself from the position of certain bioethicists ${ }^{6}$ who have expressed their philosophical opposition to allowing medical professionals to conscientiously object to providing healthcare services. While the academy continues to debate the philosophical desirability of the right to conscientious objection for medical professionals, ${ }^{7}$ policy makers in the sector, including the BMA, are bound by the terms of the law. The UK Parliament has explicitly conferred a statutory right to conscientious objection in relation to abortion and embryo research and fertility treatment. Consequently, the BMA cannot but accept that medical professionals can exercise these statutory rights. In addition, the BMA has also accepted a right to conscientious objection in the circumstances of a doctor unwilling to withdraw life-sustaining treatment from a patient lacking capacity where another doctor is available and willing to take over care. It draws legal support for this position from the Code of Practice on the Mental Capacity Act and, indirectly, from guidance provided by the High Court. ${ }^{8}$

The BMA has however rejected a full right to conscientious objection in circumstances other than the three above. It is nevertheless BMA's policy that

'there is no reason why reasonable and lawful requests by doctors to exercise a conscientious objection to other procedures should not be considered [...]. In these circumstances, conscientious objection should not be seen as a "right", but individual requests should be assessed on their merits.'

The BMA's stance is animated by various factors. First, it wishes to safeguard patients' right to a 'timely, clinically-indicated care or treatment that is provided in a supportive, sensitive and nonjudgmental manner.' Second, it is worried that a more extensive right to conscientious objection would undermine respect for medical professionalism. Third, it considers that if a significant number of doctors could opt-out of providing certain services that would undermine the NHS' mission to deliver healthcare services on the basis of need. Finally, the BMA's position is animated by the desire to avoid that doctors and their institutions be vulnerable to legal challenge for discrimination if a conscientious objector refuses to provide medical services to certain statutorily protected groups such as homosexuals. 
There is no opposition in this paper towards the reasons behind the BMA's policy. As will be shown below, some of these reasons, in particular the avoidance of discriminatory acts and the safeguarding of patients' health, will often figure in the legal analysis as to whether refusing to allow a doctor to conscientiously object disproportionately interferes with the medical professional's human right to freedom of conscience. However, as shown in the next section, these reasons can no longer be used to deny the existence of a generous legal right to conscientious objection.

\section{Eweida and the Broad Reach of the Human Right to Conscientious Objection}

The BMA's policy paper acknowledges in its initial sections that art. 9 confers 'an explicit legal right to freedom of thought, conscience and religion'. The paper also goes on to refer to the case of Eweida where the ECtHR held, among other things, that it was lawful for an NHS Trust to prevent a nurse from wearing a crucifix-necklace on health and safety grounds. Disappointingly, the BMA's paper fails to acknowledge the ground-breaking importance of Eweida for the right to conscientious objection.

Eweida concerned four different individuals, two of whom, a registrar of marriages and a relationship counsellor, were claiming they had a human right to conscientiously object to providing the services they were employed for. Prior to Eweida, the ECtHR, the European Commission on Human Rights (a semi-judicial ECHR body that has now been abolished) and the UK House of Lords (now replaced by the Supreme Court), had all held that art. 9 could not be invoked to grant a right to conscientiously object to providing the services mandated by their profession. In the case of Pichon and Sajous $v$ France, for example, the ECtHR held that there was no interference with two pharmacists' art. 9 right when they were fined for conscientiously objecting to selling contraceptive pills to three women. The reasoning of the court was that the pharmacists

'cannot give precedence to their religious beliefs and impose them on others as justification for their refusal to sell [the contraceptive pills], since they can manifest those beliefs in many ways outside the professional sphere'. ${ }^{9}$

All these institutions, prior to Eweida, had consistently denied that a professional has an art. 9 right to conscientiously object to a duty imposed by his employment. The rational was that the possibility to resign from the job enables the individual to exercise his conscientious beliefs. ${ }^{10}$ However, in Eweida, the ECtHR explicitly reversed this long-standing position and held, at paragraph 83 of the judgment, that

'Given the importance in a democratic society of freedom of religion, the Court considers that, where an individual complains of a restriction on freedom of religion in the workplace, rather than holding that the possibility of changing job would negate any interference with the right, the better approach would be to weigh that possibility in the overall balance when considering whether or not the restriction was proportionate'.

The SC has duly accepted that this position will apply in the UK in the recent case of Bull v Hall. ${ }^{11}$ The result of this stance is that UK courts can no longer automatically reject human right claims of conscientious objection from medical professionals on the ground that the professionals are free to resign from their jobs. The courts will now have to assess whether their conscientious beliefs warrant the protection of art. 9. Guidance provided by the House of Lords, which was considered 
and not rejected by the ECtHR in Eweida, indicates that a generous approach should be taken towards this question. The House of Lords said

'The belief must relate to matters more than merely trivial. It must possess an adequate degree of seriousness and importance. [...] The belief must also be coherent in the sense of being intelligible and capable of being understood. [...] Overall, these threshold requirements should not be set at a level which would deprive minority beliefs of the protection they are intended to have under the Convention'. ${ }^{12}$

The above indicates that art. 9 will apply to a wide array of scenarios where a professional objects, on conscience grounds, to performing his professional duty. In Eweida, the ECtHR held that art. 9 applied in the case of two professionals objecting to complying with their employer's dress-code policy. In the same case it held that art. 9 applied in the case of a registrar refusing to marry samesex couples and in the case of a counsellor refusing to counsel same-sex couples. In Bull $v$ Hall the SC accepted that art. 9 applied in the case of hotel owners refusing to provide accommodation to same-sex couples. The First-Tier Tribunal has also accepted that members of the Seventh-day Adventist Church who had chosen to shun computers were exempt on conscience grounds from online filing of their VAT returns. ${ }^{13}$

All these cases indicate that freedom of conscience as protected under art. 9 has a wide reach. These cases suggest that a medical practitioner will be able to invoke the protection of art. 9 well beyond the three areas accepted by the BMA. For example, it is suggested that a medical professional may invoke art. 9 to refuse to prescribe contraception, insert an implant or sterilise a patient (whether male or female) on the grounds that, as some Catholics believe, it is wrong to use contraception to prevent new human beings from coming into existence.

\section{The Human Right to Conscientious Objection is not Absolute}

As stated above and as recognised by the BMA in its policy paper, the right protected by art. 9 is not absolute. It can be overridden in circumstances detailed under paragraph 2 of art. 9, i.e. by limitations which are 'prescribed by law and are necessary in a democratic society in the interests of public safety, for the protection of public order, health or morals, or the protection of the rights and freedoms of others.' This means that the fact that art. 9 may afford protection to a conscientious objection does not at all mean that a particular objection will be automatically granted. A refusal to accommodate the objection does not necessarily violate human rights standards if it complies with art. 9(2), i.e. if it is proportionate.

Under well-established legal cases, ${ }^{14}$ determining whether a refusal to accommodate is proportionate requires establishing that the refusal

1. Is rationally connected to achieving the legitimate aims recognised under art. 9(2) (e.g. public safety, health or for the protection of the rights and freedoms of others); and

2. Is no more than reasonably necessary to achieve those aims; and

3. Strikes a fair balance between the rights of the conscientious objector and the interests of the community. 
The first two limbs of the proportionality test are not particularly controversial. A denial of a conscientious objection will almost always be rationally connected to enabling the rights of patients to receive the full spectrum of healthcare services lawfully available to them (limb 1). Also, given that one can only either accommodate or deny accommodating a conscientious objection no question arises as to whether there are other more reasonable means which may be available to deal with a conscientious objection (limb 2).

The crucial question will therefore almost always be whether denying a conscientious objection strikes a fair balance between the objector's right to freedom of conscience and the interests of the community (limb 3). Such community interests may legitimately include factors such as public access to all legally available healthcare services and upholding the values of medical professionalism. One may recall from section II above that some of these factors are those advocated by the BMA for a right to conscientious objection with a limited scope. After Eweida, under current human rights law these factors can no longer justify a right to conscientious objection with limited scope but may instead legitimately justify specific instances where that broad right can be overridden. This is of very practical importance. The existence of a broad right entails that once a doctor has made a request for conscientious objection status there is a legal duty on the NHS employer to consider that request and determine, if necessary by seeking expert legal advice, with associated expenditure, whether a refusal to grant that request is proportionate. If the request is denied, the NHS employer is at risk of legal challenge, which may or may not be successful but will be invariably expensive, by the doctor making the request.

The above entails that getting right the proportionality analysis has significant practical and financial implications for NHS employers. Unfortunately, the courts have not provided exhaustive guidance of the instances in which the broad right to conscientious objection may be overridden. However, a review of existing cases indicates that it is fairly clear that a conscientious objection may be lawfully refused either when the objection results in discrimination of a protected group or when it undermines patients' safety.

As regards the discrimination point, the courts' approach is very clear both in Eweida and in the more recent SC case of Bull $v$ Hall. Two of the applicants in Eweida, Ms Ladele and Mr McFarlane (the latter being a marriage counsellor refusing to counsel same-sex couples on grounds of his belief that same-sex unions are sinful), objected to performing their jobs in the service of same-sex couples. While recognising that art. 9 afforded protection to their conscientious refusal, the ECtHR accepted that it was proportionate for their employers to refuse to accommodate their objections as doing so would result in discrimination. The SC followed a similar path in Bull $v$ Hall when it held that it was not a disproportionate interference with the art. 9 right of the owners of a bed and breakfast to be penalised for refusing to provide a double room to a same-sex couple because of their religious belief that same-sex unions are sinful.

This approach lends support to the view held by the BMA itself (and the GMC) that conscientious objections that result in discrimination should not be allowed. While the case law so far supports this view particularly in relation to homosexual couples, it would be prudent to assume that the courts' stance would extend to other historically discriminated groups such as women or transgender individuals. 
The second circumstance where there is some legal authority for the view that conscientious objection may be lawfully refused is when the objection would undermine the health and safety of a patient. The precise boundaries of this justification are yet unclear. In Eweida, the ECtHR held that Ms Chaplin could not wear her cross-necklace during her nursing shifts as it accepted the NHS employer's position that the neckless could be a safety hazard, e.g. if it came in contact with open wounds. However, no real evidence was heard by the ECtHR on the level of likelihood and seriousness of the predicted harm. This might suggest that the 'health and safety' justification should be interpreted widely and an objection can be lawfully refused whenever this justification is invoked. One should however be cautious of endorsing this wide scope interpretation as it is inconsistent with the viability of the right to conscientious objection in some areas where it is now well-established.

Take for example the statutory conscience clause in section 4 of the Abortion Act. This allows medical professionals to conscientiously object to performing an abortion, lawful under section 1(a), even if ' $[. .$.$] the pregnancy would involve risk, greater than if the pregnancy were terminated, of$ injury to the physical or mental health of the pregnant woman'. This conscience clause effectively allows medical professionals to conscientiously object even though doing so might entail a health risk to the woman seeking an abortion. If the wide scope interpretation of the 'health and safety' justification was followed to its logical conclusion such conscience clause should be found inconsistent with the ECtHR. However, the ECtHR itself has stated that such conscience clauses in relation to abortion might well fall within art. 9's protection of conscience as long as they do not impede patients from obtaining access to services to which they are legally entitled to (usually through a referral system to a non-objecting medical professionals). ${ }^{15}$ In essence, even though doing so might entail subjecting patients to a certain level of health risk, the ECtHR has itself suggested that medical professionals may, with appropriate safeguards, lawfully object to performing abortions.

The 'health and safety' justification should therefore not be construed broadly. Its expansive use in Eweida is best relegated to the particular facts of the case and to the reluctance of the ECtHR to reach an independent conclusion not having heard sufficient evidence and deferring to the national authorities' judgement of facts. If heard by a UK court which has had the opportunity to hear evidence on all the facts, it is more likely that the 'health and safety' justification will be relegated to circumstances where a conscientious objection is invoked in an emergency situation or where there is sufficient evidence that allowing the objection could cause real and immediate harm to the patient. Under section 4(2) of the Abortion Act 1967, for example, medical practitioners cannot conscientiously object to providing an abortion where it 'is necessary to save the life or to prevent grave permanent injury to the physical or mental health of a pregnant woman.' It is submitted that the 'health and safety' justification will very likely apply to such emergency circumstances. Whether this will be accepted by UK courts in future litigation is however at this stage only the subject of speculation.

\section{v. Conclusion}

It has been argued that the BMA's current policy on conscientious objection is not aligned with recent human rights developments. These grant to medical professionals a right to conscientious objection in many more circumstances than the very few recognised by the BMA. However, this 
wide-ranging right may be overridden if the refusal to accommodate the conscientious objection is proportionate. It has been shown that it is very likely that it is lawful to refuse to accommodate conscientious objections which would result in discrimination of protected groups. It is still uncertain, however, in what particular circumstances the objection may be lawfully refused if it poses risks to the health and safety of patients. Without doubts there will be further legal developments on this issue. However what should now be clear is that the BMA's policy has not caught up with existing developments. The BMA's policy should be more closely aligned to the GMC's guidance by recognising that the right to conscientious objection cannot be confined to three specific areas and that the exercise of the right, independently of what services are being objected to, should not result in discrimination or undermine patients' health in emergency situations.

\section{REFERENCES}

${ }^{1}$ Doogan v Greater Glasgow and Clyde Health Board [2015] A.C. 640.

${ }^{2}$ Available at http://bma.org.uk/practical-support-at-work/ethics/expressions-of-doctors-beliefs (last accessed on 5 January 2016).

${ }^{3}$ BMA, 'Expression of Doctors' Beliefs'.

${ }^{4}$ General Medical Council, Personal Beliefs and Medical Practice, available at http://www.gmcuk.org/static/documents/content/Personal beliefs-web.pdf, paragraphs 8-16.

${ }^{5}$ Eweida v United Kingdom (2013) 57 E.H.R.R. 8.

${ }^{6}$ Savulescu J. Conscientious Objection in Medicine. BMJ 2006; 332: 294-297.

${ }^{7}$ Recent debates can be observed in the special journal issues on conscientious objection in Fovargue S., McGuinness S., Mullock A. et al. Conscience and Proper Medical Treatment. Med Law Rev 2015;23:173-302 and in McLeod C., Downie J. Let Conscience Be Their Guide? Conscientious Refusals in Health Care. Bioethics 2014;28:1-46.

${ }^{8}$ Re B (Adult: Refusal of Medical Treatment) [2002] EWHC 429 (Fam) at paragraph 100(viii).

${ }^{9}$ Pichon and Sajous v France [2001] ECHR 898.

${ }^{10}$ Regina (SB) v Governors of Denbigh High School [2006] UKHL 15, [23]-[25].

${ }^{11}$ Bull v Hall [2013] 1 W.L.R. 3741, paragraph 47.

${ }^{12}$ R (Williamson and Others) v. Secretary of State for Education and Employment [2005] UKHL 15, at paragraph 23.

${ }^{13}$ Blackburn v Revenue and Customs Commissioners [2013] UKFTT 525 (TC).

${ }^{14}$ See for example the SC in R (Nicklinson) v Ministry of Justice [2014] 3 WLR 200 at paragraph 310.

${ }^{15}$ P. and S. v Poland [2013] 1 FCR 476 at paragraphs 106-107. 